\title{
Nitrogen balance and myofibrillar protein turnover in double muscled Belgian Blue bulls in relation to compensatory growth after different periods of restricted feeding
}

\author{
C. Van Eenaeme, M. Evrard, J. L. Hornick, P. Baldwin, M. Diez, and L. Istasse \\ Department of Nutrition, Veterinary Faculty, University of Liège, Sart Tilman, B43 4000 Liège, Belgium. \\ E-mail:vaneena@stat.fmv.ulg.ac.be. Received 17 June 1998, accepted 7 August 1998.
}

\begin{abstract}
Van Eenaeme, C., Evrard, M., Hornick, J. L., Baldwin, P., Diez, M. and Istasse, L. 1998. Nitrogen balance and myofibrillar protein turnover in double muscled Belgian Blue bulls in relation to compensatory growth after different periods of restricted feeding. Can. J. Anim. Sci. 78: 549-559. Nitrogen balance and myofibrillar protein breakdown were studied in 16 double-muscled Belgian Blue bulls during a low growth period $\left(0.5 \mathrm{~kg} \mathrm{~d}^{-1}\right)$ (LGP) of 4 mo (L4), 8 mo (L8), or 14 mo (L14) and the subsequent fattening period (rapid growth period, RGP). The control group (CG) was given a conventional fattening diet; the others received a low-energy, low-protein diet during LGP, and the same diet as the CG during RGP. Measurements were made halfway through the LGP, 1 mo after the beginning of the fattening period, and 1 mo before slaughter. Nitrogen balance was about half of CG $(P<0.001)$ during LGP, e.g., 50.8, 21.3, 25.8, and $23.8 \mathrm{~g} \mathrm{~d}^{-1}$, for CG, L4, L8, and L14, respectively. Between LGP and RGP, $\mathrm{N}$ balance increased by about $18 \mathrm{~g} \mathrm{~N} \mathrm{~d}^{-1}$ above the control in the compensating groups L4, L8 and L14. This was due to the higher digestibility and the higher metabolizability of the nitrogen in the fattening diet. Lower muscle protein accretion during the LGP resulted from decreased synthesis $(P<0.001)$ and degradation $(P<0.05)$ compared with the GC. When changing to RGP different evolution patterns were observed in the three formerly restricted groups, e.g. after a short restriction (L4) both synthesis and degradation rose during the RGP but declined towards the end. After a longer restriction (L8 and L14), synthesis and degradation increased and remained high. The magnitude of these increases was inversely proportional to the length of the restriction period.
\end{abstract}

Key words: Belgian Blue bulls, compensatory growth, nitrogen balance, muscle, muscle protein breakdown

\begin{abstract}
Van Eenaeme, C., Evrard, M. Hornick, J. L., Baldwin, P., Diez, M. et Istasse, L. 1998. Bilan azoté et turnover de la protéine myofibrillaire chez le taurillon blanc bleu belge culard en relation avec croissance compensatrice suivant une période de restriction alimentaire de durées variables. Can. J. Anim. Sci. 78: 549-559. Le bilan azoté et la dégradation de la protéine musculaire ont été estimés chez 16 taurillons culards Blanc Bleu Belge. Ceux-ci ont été soumis à une période de croissance faible (LGP) $\left(0.5 \mathrm{~kg} \mathrm{j}^{-1}\right)$ de 4 (L4), 8 (L4) ou 14 mois (L14), suivie d'une période de croissance accélérée (RGP). Le groupe témoin (CG) reçevait une ration d'engraissement classique tandis que les 3 autres groupes reçevaient durant la LGP une ration limitée en énergie et en protéine et la même ration d'engraissement que le groupe témoin en période RGP. Les mesures ont été effectuées au milieu de la période de LGP, 1 mois après le passage à la ration d'engraissement et un 1 mois avant l'abattage. En LGP le bilan azoté a été de moitié inférieur à celui du groupe témoin $(P<0.001)$. En croissance compensatrice, le bilan $\mathrm{N}$ a augmenté d'environ $18 \mathrm{~g}$ par rapport au groupe témoin. Cet effet résultait d'une meilleure digestibilité et d'une meilleure métabolisabilité de l'azote de la ration d'engraissement. Le dépôt protéique plus faible en LGP provenait d'une diminution simultanée de la synthèse $(P<0.001)$ et de la dégradation protéique $(P<0.05)$, par rapport au CG. Après une courte periode de restriction (L4), la synthèse et la dégradation protéique ont augmenté puis ont diminué vers la fin de l'expérience. Après des périodes de restriction plus longues (L8 et L14), elles ont augmenté de façon permanente. Cependant, l'amplitude de ces augmentations a été inversément proportionnelle à la longueur de la période de restriction.
\end{abstract}

Mots clés: Taurillons Blanc Bleu Belge, croissance compensatoire, bilan azoté, muscle, dégradation protéine musculaire

Belgian Blue double muscled bulls are well-known for their excellent slaughter, carcass, and meat traits (Istasse et al. 1990). To achieve this large meat yield, the bulls have to lay down huge amounts of skeletal muscle during their lifetime. As skeletal muscle dry matter is chiefly muscle protein, especially in BBDM, muscle growth is mainly protein accretion. Slight variations in MPS and MPD rates can result in proportionally large changes in MPA. So MP turnover plays a capital role in the net result, i.e., meat production.

\footnotetext{
Abbreviations: AAN, amino acid nitrogen; ADG, average daily gain; BBDM, Belgian Blue double muscled bulls; CG, control group; L4, 4 mo restricted group; L8, 8 mo restricted group; L14, 14 mo restricted group; FBR, fractional breakdown rate; FCR, feed conversion ratio; Kd, fractional rate of muscle protein degradation; Ks, fractional rate of muscle protein synthesis; $\mathbf{K g}$, fractional rate of muscle protein accretion; LGP, low growth period; $\mathbf{L} \mathbf{W}^{\mathbf{0 . 7 5}}$, metabolic liveweight; $\mathbf{M C P}$, multicatalytic proteinase; MP, muscle protein; MPA, muscle protein accretion; MPD, muscle protein degradation; MPS, muscle protein synthesis; RGP, rapid growth period; $\mathbf{3} \mathbf{M H}, \mathbf{N}^{\tau}$-methylhistidine; $\Delta \mathbf{M E}$, change in metabolisable energy; $\Delta \mathbf{N}$, change in nitrogen; $\Delta \mathbf{N}$ ret, change in nitrogen retention; $\Delta \mathbf{N}$ dig, change in nitrogen digestion; $\Delta \mathbf{N}$ ur, change in urinary nitrogen excretion
} 
Nutritional status is known to influence MP turnover to a large extent. Earlier experiments with rats (Haverberg et al. 1975; Millward et al. 1975) showed that nutritional restriction lowered growth rate by decreasing concomitantly MPS and MPD rates. Realimentation to an adequate diet resulted in rapid growth, brought about by increases in both MPS and MPD. Estimation of MP turnover in beef cattle during feed restriction and subsequent realimentation has not been reported extensively. Jones et al. (1990) measured myofibrillar MP turnover in crossbred steers, whereas Van Eenaeme et al. (1992) reported on MP turnover in dual purpose type Belgian Blue intact bulls. Although in both papers a control group was compared to a restricted and realimented group, substantial differences in animals, diets, and duration of restriction were imposed between the experiments reported. In the present paper, $\mathrm{N}$ balance and MP turnover will be examined in double muscled Belgian Blue bulls subjected to growth restriction of different durations, followed by a period of rapid compensatory growth.

\section{MATERIAL AND METHODS}

\section{Animals and Treatments}

The Animal Care and Use Council of the Veterinary Faculty, University of Liège approved the use and treatment of animals in this study. A total of 16 Belgian Blue bulls double muscled type, initial liveweight and age of $313.7 \pm$ $23.0 \mathrm{~kg}$ and $10.2 \pm 1.15 \mathrm{mo}$, were used. They were randomly penned in metabolic stalls and maintained on it during the whole experimental period. The animals of the CG were fed a high-energy, high-protein diet composed of dried sugar beet pulp, grains, soybean meal and a mineral mixture. The animals of groups 2, 3, and 4 (L4, L8, L14) were initially fed a restricted amount of a low energy, low protein diet calculated to allow a growth rate of $0.5 \mathrm{~kg} \mathrm{~d}^{-1}$. This diet was based on pelleted straw, dried alfalfa, grains, soybean meal and a mineral mix. This LGP lasted for 114, 243, and $419 \mathrm{~d}$, respectively, in $\mathrm{L} 4, \mathrm{~L} 8$, and L14, corresponding to a short, a medium and an extreme length period. At the end of this period of restriction, the animals were offered, on an ad libitum basis, the same fattening diet as CG (RGP), with a transition period of $15 \mathrm{~d}$ allowed between the two periods. The composition of the diets is reported in Table 1.

On three occasions during the experiment, $\mathrm{N}$ balance and urinary excretion of $\mathrm{N}^{\tau}$-methylhistidine $(3 \mathrm{MH})$, an in vivo non-invasive marker of estimating MPD (Harris and Milne 1981), were measured during 8-d sampling periods (Fig. 1). In $\mathrm{CG}$, the measurements were performed at the beginning (P1) and halfway through the fattening period (P2) and $1 \mathrm{mo}$ before slaughter (P3). In L4, L8, and L14, corresponding measurements were performed halfway through the LGP (P1), 1 mo after the end of the transition period, i.e., in the rapid growth period (RGP) (P2), and 1 mo before slaughter (P3).

Feed intake was recorded daily and liveweight was determined at 2 wk intervals.

\section{Urine and Faecal Collections}

Twenty-four-hour total collection samples of urine and faeces were obtained daily for $8 \mathrm{~d}$. Urine was collected in plastic containers to which $100 \mathrm{~mL}$ of $\mathrm{H}_{2} \mathrm{SO}_{4}(9 \mathrm{~N})$ was added

\begin{tabular}{lcc}
\hline Table 1. Composition of the diets & \multicolumn{2}{c}{} \\
& \multicolumn{2}{c}{ Period } \\
\cline { 2 - 3 } Item & LGP $^{\mathbf{z}}$ & RGP $^{\mathbf{y}}$ \\
\hline Dry matter, (\%) & 87.9 & 87.2 \\
Ingredients (\% DM) & & \\
Sugar beet pulp & 7.7 & 38.1 \\
Barley & 5 & 8.1 \\
Maize & - & 8.1 \\
Spelt & 5.4 & 8.1 \\
Middlings & 5 & 8.1 \\
Soy bean meal & 1.8 & 11.3 \\
Linseed meal & - & 3.6 \\
Molasses & 1.4 & 3.6 \\
Dried lucerne & 8 & - \\
Pelleted straw & 54.1 & - \\
Straw & 9.8 & 9.8 \\
Mineral mixture & 1.6 & 1.1 \\
Chemical analysis $\left(\mathrm{g} \mathrm{kg}^{-1}\right.$ of $\left.\mathrm{DM}\right)$ & & \\
Organic matter & 912.2 & 924.5 \\
Crude protein & 113.7 & 156.8 \\
Ether extract & 18.2 & 25.7 \\
Acid detergent fiber & 392.2 & 244.8 \\
Ca & 9 & 10.1 \\
P & 4.3 & 4.6 \\
\hline
\end{tabular}

zow growth period.

$\mathbf{y}_{\text {Rapid growth period. }}$

daily in order to avoid $\mathrm{N}$ losses by volatilisation of ammonia. Urine and faeces were mixed and weighed and representative samples obtained for Kjeldahl analysis.

Evaporation losses from skin were calculated as $0.018 \times$ $\mathrm{kg}^{0.75} \mathrm{LW}$ in $\mathrm{g} \mathrm{N} \mathrm{d}^{-1}$

\section{Chemical Analysis}

Nitrogen in urine, faeces, and feed was measured in daily samples by a semi-automated Kjeldahl procedure using a Tecator Block digestor for ashing and an automated determination of the formed ammonia by the Berthelot method using a Technicon Auto Analyzer II. Urinary 3MH was determined after acid hydrolysis, in order to liberate $3 \mathrm{MH}$ from balenine, by fused silica capillary gas chromatography as the N-heptafluorobutyryl isobutyl esters by a method adapted from those of McKenzie and Tenaschuk (1979a,b)

\section{Slaughter Procedure and Measurements}

Animals were slaughtered when liveweight gain recorded on two consecutive weighing during RGP was below $1 \mathrm{~kg}$ $\mathrm{d}^{-1}$. At the slaughterhouse, animals were stunned and bled. Head, feet, skin, tail and fifth quarter were successively removed. Abdominal fat was also removed from the carcass. These operations took about $50 \mathrm{~min}$, after which hot carcass weight was recorded.

Two days after slaughter the 7th, 8th and 9th ribs were removed from the carcass. They were dissected to separate lean meat, fat and connective tissue and bones. Regressions of Martin and Torreele (1962) for double muscled cattle were used to assess the composition of the carcass.

\section{Calculations}

From $\mathrm{N}$ balance and urinary $3 \mathrm{MH}$ excretion, the components of muscle protein turnover were estimated. 


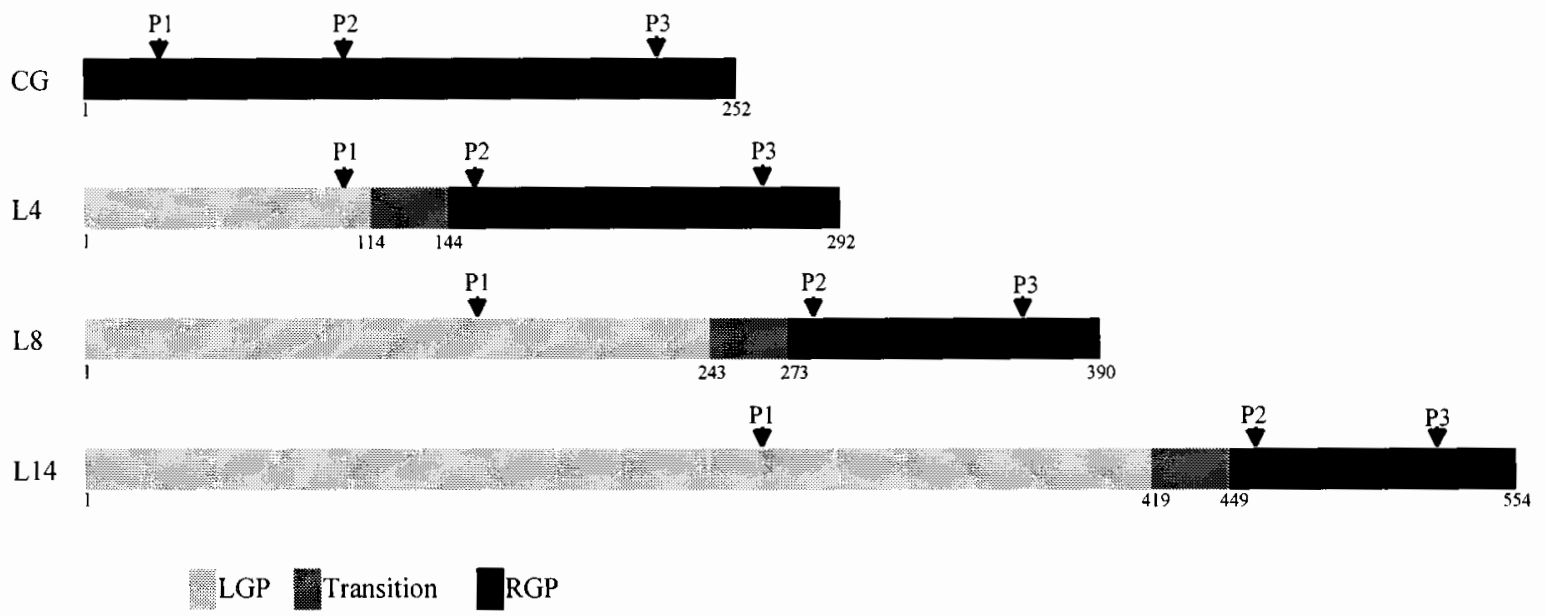

Fig. 1. Experimental design for three treatments groups differing in length of the period of low growth (114 d for L4, $243 \mathrm{~d}$ for L8 and 419 $\mathrm{d}$ for L14) before fattening and for a control fattening group (CG). Arrows indicate sampling periods: Period 1 (P1), Period 2 (P2) and Period 3 (P3).

1) MPA was assumed as retained $\mathrm{N}$ (from $\mathrm{N}$ balance in $\mathrm{g}$ $\left.\mathrm{d}^{-1}\right) \times 6.25$.

2) MPD was derived from urinary $3 \mathrm{MH}$ excretion ( $\mu \mathrm{mol}$ $\mathrm{d}^{-1}$ ) divided by $3.51 \mu \mathrm{mol} \mathrm{g}{ }^{-1}$, the content of $3 \mathrm{MH}$ in skeletal muscle protein (Nishizawa et al. 1979; Van Eenaeme et al. 1983).

Urinary $3 \mathrm{MH}$ excretion was assumed to be a valid and noninvasive index of in vivo MPD (Harris and Milne 1981). The size of the $3 \mathrm{MH}$ pool in skeletal muscle, needed for calculation of fractional turnover rates, was estimated from dressing percentage, meat content in carcass and protein and dry matter composition of muscle.

3) MPS was approximated as MPA + MPD.

Results were expressed as $\mathrm{g} \mathrm{MP} \mathrm{d}^{-1}$

\section{Statistical Analysis}

Animal performances data were analyzed per growth period by a one way analysis of variance (ANOVA). When statistical significance was obtained, means were compared by a Scheffé test.

As the control group was given the fattening diet during the whole experiment, while the other groups received the LGP diet during the P1 and the RGP diet during the other two periods, a crossed two factor ANOVA period ( group could not be applied. Consequently, nitrogen balance and muscle protein turnover were analyzed by group and by period by a one-way ANOVA test. When statistical significance was obtained, means were compared by a Scheffé test.

\section{RESULTS}

\section{Animal Performances}

Initial weight was around $300 \mathrm{~kg}$ in all four groups (Table 2). In the CG, ADG and FCR were $1.3 \mathrm{~kg} \mathrm{~d}^{-1}$ and $7.37 \mathrm{~kg} \mathrm{~kg}^{-1}$, respectively. Due to the differing durations of the LGP in the three restricted groups, liveweight and total concentrate intake at the end of the LGP increased from groups 2 to 4 (L4, L8 and L14), e.g. 367.7, 434.9 and
$485.7 \mathrm{~kg}(P<0.01)$ and 672,1411 and $2618 \mathrm{~kg}(P<0.001)$, respectively. Corresponding ADG was about $0.5 \mathrm{~kg} \mathrm{~d}^{-1}$ and decreased slightly from L4 to L14 $(P<0.01)$. FCR was similar for L4 and L8 but was higher in L14 $(P<0.001)$ (Table 2). During the RGP, total gain was higher in L4 than in L8 and L14 $(P<0.01)$. The length of the RGP decreased from L4 to L14 in inverse relation to the length of the preceeding LGP $(P<0.001)$. ADG was higher in the compensating groups $(P<0.05)$ while FCR was not significantly different from $\mathrm{CG}$.

\section{Nitrogen Balance and Components}

In the $\mathrm{CG}, \mathrm{N}$ retention was close to $50 \mathrm{~g} \mathrm{~N} \mathrm{~d}^{-1}$ during Periods 1, 2 and 3 (Table 3 ). In the restricted groups, $\mathrm{N}$ balance was slightly over $20 \mathrm{~g} \mathrm{~d}^{-1}$ during the LGP and differed from $\mathrm{CG}(P<0.001)$.

$\mathrm{N}$ balance increased $(P<0.01, P<0.001)$ to values higher than in the control during compensatory growth (about $\left.68 \mathrm{~g} \mathrm{~d}^{1}\right)$. One month before slaughter, $\mathrm{N}$ retention remained high in L4 and L8 and increased even in L14 $(P<0.01)$.

On a metabolic body weight basis, $\mathrm{N}$ retention in $\mathrm{CG}$ declined from Periods 1 to 3 (Table 3). During restriction, it was markedly lower $(P<0.001)$ and it increased above the level of the CG during compensatory growth $(P<0.05$ for L4 and L8, $P<0.01$ for L14). One month before slaughter, $\mathrm{N}$ retention per $\mathrm{kg}^{0.75} \mathrm{LW}$ decreased in $\mathrm{L} 4$ and L8 but still tended to increase in L14, remaining higher than in $\mathrm{CG}$ $(P<0.06)$.

When expressed as a percentage of $\mathrm{N}$ intake (Fig. 2), $\mathrm{N}$ retention in CG declined continuously from $30 \%$ to about $25 \%$ with the advancement of the fattening period. In L4, L8 and L14, it was lower during LGP and increased to about $33 \%$ during $\mathrm{P} 2$, declining thereafter to $26 \%$ in L4 and L8 while in L14 it remained almost constant (30\%) during the two measurement periods of the fattening period.

In the $\mathrm{CG}, \mathrm{N}$ intake increased from $\mathrm{P} 1$ to $\mathrm{P} 2$ and $\mathrm{P} 3$ $(P<0.05, P<0.001)$. In L4, L8, and L14, N intake was lim- 
Table 2. Animal performances during constant fattening (CG) or during LGP lasting for 4, 8, or 14 mo (L4, L8, L14) prior to a fattening period (RGP), in addition to slaughter data in Belgian Blue double muscled bulls

\begin{tabular}{|c|c|c|c|c|c|c|}
\hline \multirow[b]{2}{*}{ Parameter } & \multicolumn{4}{|c|}{ Group } & \multirow[b]{2}{*}{$P>F$} & \multirow[b]{2}{*}{ SEM } \\
\hline & $\mathrm{CG}$ & L4 & L8 & L14 & & \\
\hline \multicolumn{7}{|l|}{ Low growth period } \\
\hline Initial weight $(\mathrm{kg})$ & & 301.9 & 306.1 & 302.7 & NS & 12.88 \\
\hline Total weight gain $(\mathrm{kg})$ & & $65.8 a$ & $128.8 b$ & $183.1 c$ & $* * *$ & 6.33 \\
\hline Length of period (d) & & $114.7 a$ & $238.6 b$ & $411.2 c$ & $* * *$ & 3.42 \\
\hline Average daily gain $\left(\mathrm{kg} \mathrm{d}^{-1}\right)$ & & $0.57 a$ & $0.54 a$ & $0.44 b$ & $* *$ & 0.023 \\
\hline Daily feed intake $\left(\mathrm{kg} \mathrm{d}^{-1}\right)$ & & $5.9 a$ & $5.9 a$ & $6.4 c$ & + & 0.13 \\
\hline Feed conversion ratio $\left(\mathrm{kg} \mathrm{kg}^{-1}\right)(1)$ & & $10.21 a$ & $11.12 b$ & $14.42 c$ & $* * *$ & 0.33 \\
\hline \multicolumn{7}{|l|}{ Rapid growth period } \\
\hline Initial weight $(\mathrm{kg})$ & $300.5 a$ & $401.9 b$ & $473.6 c$ & $533.6 d$ & $* *$ & 14.46 \\
\hline Total weight gain $(\mathrm{kg})$ & $330.2 a$ & $220.0 b$ & $172.9 c$ & $171.2 c$ & $* *$ & 10.44 \\
\hline Length of period (d) & $252.3 a$ & $146.6 b$ & $120.2 c$ & $111.6 c$ & $* * *$ & 4.57 \\
\hline Average daily gain $\left(\mathrm{kg} \mathrm{d}^{-1}\right)$ & $1.32 a$ & $1.51 b$ & $1.43 a b$ & $1.53 b$ & $*$ & 0.86 \\
\hline Daily feed intake $\left(\mathrm{kg} \mathrm{d}^{-1}\right)$ & $9.7 a$ & $11.8 c$ & $10.7 b$ & $12.1 c$ & + & 0.33 \\
\hline Feed conversion ratio $\left(\mathrm{kg} \mathrm{kg}^{-1}\right)$ & 7.37 & 7.71 & 7.53 & 7.92 & NS & 0.16 \\
\hline \multicolumn{7}{|l|}{ Slaughter characteristics } \\
\hline Slaughter weight $(\mathrm{kg})$ & $620.6 a$ & $613.4 a$ & $630.2 a$ & $693.3 b$ & $*$ & 17.09 \\
\hline Warm carcass weight $(\mathrm{kg})$ & $398.9 a$ & $390.4 a$ & $396.2 a$ & $447.0 \mathrm{~b}$ & $* *$ & 11.52 \\
\hline Dressing percentage $(\%)$ & $64.3 a$ & $63.6 a b$ & $62.9 b$ & $64.5 a$ & $*$ & 0.41 \\
\hline \multicolumn{7}{|l|}{ Carcass composition ( $k g$ ) } \\
\hline Muscle & $298.5 a$ & $285.5 a$ & $285 a$ & $334.4 b$ & $* *$ & 8.36 \\
\hline Connective and adipose tissue & $49.6 a$ & $53.3 a b$ & $59.5 b c$ & $64.0 c$ & $*$ & 3.00 \\
\hline Bone & 51.7 & 51.6 & 50.4 & 54.3 & NS & 1.65 \\
\hline
\end{tabular}

zReported on the basis of air dry values of feed

$a-d$ Means within a row with common letter do not differ at $\mathrm{P}<0.05$

$+,{ }^{*}, * *, * * * P<0.1, P<0.05, P<0.01, P<0.001$, respectively; NS, not significant.

ited to about $100 \mathrm{~g} \mathrm{~N} \mathrm{~d}^{-1}$ in LGP and was doubled during RGP, being equivalent to or higher than in $\mathrm{CG}(P<0.001)$ and corresponding, to some extent, to compensatory intake. (Table 3). At the end of the experiment $\mathrm{N}$ intake was around $250 \mathrm{~g} \mathrm{~d}^{-1}$ in all groups. On metabolic weight basis, it was about half the control value during restriction $(P<0.001)$. During $\mathrm{P} 2, \mathrm{~N}$ intake was around $2 \mathrm{~g} \mathrm{~d}^{-1} \mathrm{~kg}^{-0.75} \mathrm{LW}$ in all groups and remained similar at the end of the experiment.

In the $\mathrm{CG}$, faecal $\mathrm{N}$ was around $60 \mathrm{~g} \mathrm{~d}^{-1}$ and increased slightly during the experiment (NS). As $\mathrm{N}$ intake increased to a greater extent, apparent digested $\mathrm{N}$ increased from $\mathrm{P} 1$ to P2 $(P<0.01)$ and P3 $(P<0.001)$. In L4, L8, and L14, faecal $\mathrm{N}$ increased in a similar way as intake, although not to the same extent. Consequently, apparent $\mathrm{N}$ digestibility increased from P1 to P3 in all groups. Thus, when the changeover in diets occurred, the increase in $\mathrm{N}$ digestibility was somewhat larger in the compensatory growth groups (significance: $P<0.094,0.025 ; 0.036$, and 0.034 , respectively, for CG, L4, L8, and L14).

As with $\mathrm{N}$ intake, a compensatory effect was also seen, to some extent, for digested $\mathrm{N}$. There also appeared to be some differences in the kinetics of increase between the three experimental groups, with the amplitude of the increase declining from L4 to L8 and L14. On a metabolic weight basis, apparent digested $\mathrm{N}$ (Table 3) doubled upon realimentation $(P<0.001)$,e.g., from around 0.7 to about $1.40 \mathrm{~g}$ $\mathrm{N} \mathrm{kg}^{-0.75} \mathrm{LW}$. The latter value was similar to those observed in the $\mathrm{CG}$.
Urinary $\mathrm{N}$ excretion rose with increasing $\mathrm{N}$ intake from P1 to P3 in all groups. Values increased in CG from 57.5 to $77.2(P<0.05)$ and then to $121.5(P<0.001)$, in L4 from 40.3 to $65.1(P<0.01)$ and then to $125.4(P<0.01)$, in L8 values increased from 40.5 to $73.7(P<0.01)$ and then to $102.9(P<0.01)$, and in L14 values increased from 37.5 to $88.6(P<0.01)$ and then to $104.9 \mathrm{~g} \mathrm{~N} \mathrm{~d}^{-1}(P<0.05)$, respectively for P1, P2 and P3.

Urinary $\mathrm{N}$ excretion per $\mathrm{kg}^{0.75} \mathrm{LW}$ followed a similar pattern. However, expressed as a percentage of ingested $\mathrm{N}$ (Fig. 2), differences appeared between groups. In CG, a steady increase was observed over the three periods, e.g., 33.9, $40.5(P<0.05)$, and $49.1(P<0.01)$. In L4 and L8, a minimum was observed during the period of maximal compensatory growth. Values for L4 were 40.1, 34.2 (NS), and $50.0(P<0.05)$, those for L8 were 41.1, 36.0 (NS), and 44.7 (NS), while for L14 they were almost constant at 38.1, 39.9, and $40.9 \%$ (NS), respectively, for periods 1,2 and 3 .

When urinary $\mathrm{N}$ was related as a percentage to apparent digested $\mathrm{N}$, a gradual increase was observed in CG (52.4, 59.7 , and $66.6 \%$ ), whereas, in the restricted and realimented groups, a tendency for values higher than those of controls was observed during LGP: e.g., $63.9(P<0.05), 63.5$, and $59.5 \%$ in L4, L8, and L14, respectively. During P2, the ratio urinary $\mathrm{N}$ to digested $\mathrm{N}$ tended to decrease in all groups, although more in L4 and L8 (48.6, 51.3 and 55.6\% in L4, L8, and L14, respectively, $P<0.10$ ). During $\mathrm{P} 3$, this ratio increased almost to control values, although more so in L4 and 
Table 3. $\mathrm{N}$ intake, $\mathrm{N}$ digested, and $\mathrm{N}$ balance in $\mathrm{g} \mathrm{d}^{-1}$ and on metabolic weight basis on three measurement periods: low growth (Period 1), rapid growth (Period 2), and 1 mo before slaughter (Period 3) for 3 treatment groups differing in length of the period of low growth (114 d for L4, $243 \mathrm{~d}$ for $\mathrm{L8}$ and $419 \mathrm{~d}$ for L14.) and for a CG at corresponding times

\begin{tabular}{|c|c|c|c|c|c|c|c|}
\hline \multirow[b]{2}{*}{ Item } & & \multicolumn{4}{|c|}{ Group } & \multirow[b]{2}{*}{$P>F$} & \multirow[b]{2}{*}{ SEM } \\
\hline & & $\mathrm{CG}$ & $\mathrm{L} 4$ & L8 & L14 & & \\
\hline \multicolumn{8}{|l|}{ Period 1} \\
\hline \multirow[t]{2}{*}{$\mathrm{N}$ intake } & $\mathrm{g} \mathrm{d}^{-1}$ & $169.28 a f$ & $100.57 b f$ & $98.43 b f$ & $98.43 b f$ & $* * *$ & 4.871 \\
\hline & $\mathrm{g} \mathrm{d}^{-1} \mathrm{~kg}^{-0.75} \mathrm{LW}$ & $2.14 a f$ & $1.2 b f$ & $1.1 c f$ & $1.05 c f$ & $* * *$ & 0.028 \\
\hline \multirow[t]{2}{*}{ Digested N } & $\mathrm{g} \mathrm{d}^{-1}$ & $109.72 a f$ & $63.09 b f$ & $63.67 b f$ & $62.95 b f$ & $* * *$ & 3.410 \\
\hline & $\mathrm{g} \mathrm{d}^{-1} \mathrm{~kg}^{-0.75} \mathrm{LW}$ & $1.38 a$ & $0.75 b f$ & $0.71 \mathrm{bf}$ & $0.67 c f$ & $* * *$ & 0.027 \\
\hline \multirow[t]{2}{*}{$\mathrm{N}$ balance } & $\mathrm{g} \mathrm{d}^{-1}$ & $50.77 a$ & $21.28 b f$ & $25.85 b f$ & $23.78 b f$ & $* * *$ & 3.071 \\
\hline & $\mathrm{g} \mathrm{d}^{-1} \mathrm{~kg}^{-0.75} \mathrm{LW}$ & $0.642 a$ & $0.254 b f$ & $0.240 b f$ & $0.256 b f$ & $* * *$ & 0.037 \\
\hline \multicolumn{8}{|l|}{ Period 2} \\
\hline \multirow[t]{2}{*}{$\mathrm{N}$ intake } & $\mathrm{g} \mathrm{d}^{-1}$ & $190.44 e$ & $190.55 e$ & $204.77 e$ & $221.83 e$ & $* *$ & 4.571 \\
\hline & $\mathrm{g} \mathrm{d}^{-1} \mathrm{~kg}^{-0.75} \mathrm{LW}$ & $1.96 e$ & $1.99 e$ & $1.93 e$ & $1.93 e$ & NS & 0.063 \\
\hline \multirow[t]{2}{*}{ Digested N } & $\mathrm{g} \mathrm{d}^{-1}$ & $129.41 e$ & $133.93 e$ & $143.77 e$ & $159.37 e$ & $* *$ & 4.311 \\
\hline & $\mathrm{g} \mathrm{d}^{-1} \mathrm{~kg}^{-0.75} \mathrm{LW}$ & 1.33 & $1.4 e$ & $1.35 e$ & $1.39 e$ & NS & 0.048 \\
\hline \multirow[t]{2}{*}{$\mathrm{N}$ balance } & $\mathrm{g} \mathrm{d}^{-1}$ & 50.45 & $67.0 e$ & $68.15 e$ & $68.73 e$ & NS & 5.775 \\
\hline & $\mathrm{g} \mathrm{d}^{-1} \mathrm{~kg}^{-0.75} \mathrm{LW}$ & 0.522 & $0.699 e$ & $0.645 e$ & $0.6 \mathrm{e}$ & NS & 0.066 \\
\hline \multicolumn{8}{|l|}{ Period 3} \\
\hline \multirow[t]{2}{*}{$\mathrm{N}$ intake } & $\mathrm{g} \mathrm{d}^{-1}$ & $247.43 d$ & $250.27 d$ & $230.36 d$ & $255.96 d$ & NS & 8.611 \\
\hline & $\mathrm{g} \mathrm{d}^{-1} \mathrm{~kg}^{-0.75} \mathrm{LW}$ & 1.99 & 2.00 & 1.88 & 2.07 & NS & 0.088 \\
\hline \multirow[t]{2}{*}{ Digested N } & $\mathrm{g} \mathrm{d}^{-1}$ & $182.24 d$ & $193.37 d$ & $167.58 d$ & $183.43 e$ & NS & 7.765 \\
\hline & $\mathrm{g} \mathrm{d}^{-1} \mathrm{~kg}^{-0.75} \mathrm{LW}$ & 1.47 & $1.55 d$ & $1.37 e$ & $1.49 e$ & NS & 0.071 \\
\hline \multirow[t]{2}{*}{$\mathrm{N}$ balance } & $\mathrm{g} \mathrm{d}^{-1}$ & 58.54 & $65.68 e$ & $62.5 e$ & $76.31 e$ & NS & 5.128 \\
\hline & $\mathrm{g} \mathrm{d}^{-1} \mathrm{~kg}^{-0.75} \mathrm{LW}$ & 0.473 & $0.528 e$ & $0.511 e$ & $0.616 e$ & NS & 0.047 \\
\hline \multicolumn{8}{|l|}{$P>F$} \\
\hline \multirow[t]{2}{*}{$\mathrm{N}$ intake } & $\mathrm{g} \mathrm{d}^{-1}$ & $* * *$ & $* * *$ & $* * *$ & $* * *$ & & \\
\hline & $\mathrm{g} \mathrm{d}^{-1} \mathrm{~kg}^{-0.75} \mathrm{LW}$ & $* *$ & $* * *$ & $* * *$ & $* * *$ & & \\
\hline \multirow[t]{2}{*}{ Digested N } & $\mathrm{g} \mathrm{d}^{-1}$ & $* * *$ & $* * *$ & $* * *$ & $* * *$ & & \\
\hline & $\mathrm{g} \mathrm{d}^{-1} \mathrm{~kg}^{-0.75} \mathrm{LW}$ & NS & $* * *$ & $* * *$ & $* * *$ & & \\
\hline \multirow[t]{2}{*}{$\mathrm{N}$ balance } & $\mathrm{g} \mathrm{d}^{-1}$ & NS & $* *$ & $* * *$ & $* * *$ & & \\
\hline & $\mathrm{g} \mathrm{d}^{-1} \mathrm{~kg}^{-0.75} \mathrm{LW}$ & NS & $* *$ & $* *$ & $* * *$ & & \\
\hline
\end{tabular}

$a-c$ Effect of nutritional treatment. Means with different letters within a row differed at $P<0.05$

$d-f$ Effect of period. Means referring to similar items and with different letters within a column differed at $P<0.05$

$+, * * * * * * P<0.1, P<0.05, P<0.01$, and $P<0.001$, respectively; NS, not significant.

L8 (64.8 and 61.4\%) than in L14 (57.2\%), which remained different from CG $(P<0.05)$. In addition, not only $\mathrm{N}$ balance but also the efficiency of $\mathrm{N}$ retention, expressed as the ratio retained $\mathrm{N} /$ apparently digested $\mathrm{N}$, increased during compensatory growth, both on an absolute and a metabolic weight basis: e.g. from $33.7,33.9$, and 37.8 to $50.1,47.4$, and $43.1 \%$, respectively, for $\mathrm{L} 4, \mathrm{~L} 8$, and $\mathrm{L} 14$. One month before slaughter, $\mathrm{N}$ retention efficiency declined to 34.0 and $37.3 \%$ in L4 and L8, respectively, but remained high in L14, with a value of $41.6 \%$. In the CG, the efficiency of $\mathrm{N}$ retention declined from 46.3 to 39.0 and 32.1 from P1 to P3.

\section{Muscle Protein Breakdown and Approximation of Muscle Protein Turnover}

Rates of synthesis, degradation, and accretion are depicted in Fig. 3. Fractional rates calculated on MP pool size estimated from carcass and muscle analysis results are given in Table 4. Evolution of MPA is similar to $\mathrm{N}$ balance, from which it was derived. MPD, estimated from $\mathrm{N}^{\tau}$-MH excretion, increased regularly with time in the CG from 576 to 743 , and then to $890 \mathrm{~g} \mathrm{MP} \mathrm{d}^{-1}$ during P1, P2 and P3. During LGP, MPD was at about 200 to $250 \mathrm{~g} \mathrm{MP} \mathrm{d}^{-1}$ lower $(P<0.05)$ in the restricted groups than in CG. During compensatory growth MPD increased. The magnitude of the increase was, however, inversely proportional to the length of the preceeding feed restriction period, with MPD rising numerically to $856 \mathrm{~g} \mathrm{MP} \mathrm{d}^{-1}$ (NS) in L4, $668 \mathrm{~g} \mathrm{MP} \mathrm{d}^{-1}$ in L8 $(P<0.05)$, but to only $269 \mathrm{~g} \mathrm{MP} \mathrm{d}^{-1}$ (NS) in L14. During P3 different levels and evolution patterns were observed, with MPD decreasing to $701 \mathrm{~g} \mathrm{MP} \mathrm{d}^{-1}$ in L4 (NS), while it increased further in the other groups, to 980 (NS) and $385 \mathrm{~g}$ $\mathrm{MP} \mathrm{d}^{-1}(P<0.07)$ in L8 and L14, respectively.

MPS, approximated as MPA + MPD, increased steadily throughout the three periods. In the CG, values were 893, 1058 ( NS ) and $1255 \mathrm{~g} \mathrm{MP} \mathrm{d}^{-1}(P<0.05)$ for P1, P2 and P3 respectively. During restriction it was lower $(\mathrm{i} P<0.001)$ in all three groups: 343,444 , and $389 \mathrm{~g} \mathrm{MP} \mathrm{d}^{-1}$ for P1, P2 and P3 respectively. During compensatory growth, MPS almost tripled in L4 and L8, with values of 1325 and $1094 \mathrm{~g} \mathrm{MP} \mathrm{d}^{-1}$ $(P<0.05)$ respectively, and doubled at $698 \mathrm{~g} \mathrm{MP} \mathrm{d}^{-1}$ $(P<0.01)$ in L14. During P3, MPS tended to decline to $1112 \mathrm{~g} \mathrm{MP} \mathrm{d}^{-1}(P<0.1)$ in L4, but increased further to 1372 $(P<0.1)$ and $862 \mathrm{~g} \mathrm{MP} \mathrm{d}^{-1}(P<0.01)$ in L8 and L14, respectively, the latter level remaining numerically lower than in the other two groups.

Fractional rates of MP turnover, in which accretion, degradation, and synthesis rates are expressed on basis of the MP pool size, were calculated in order to take into 


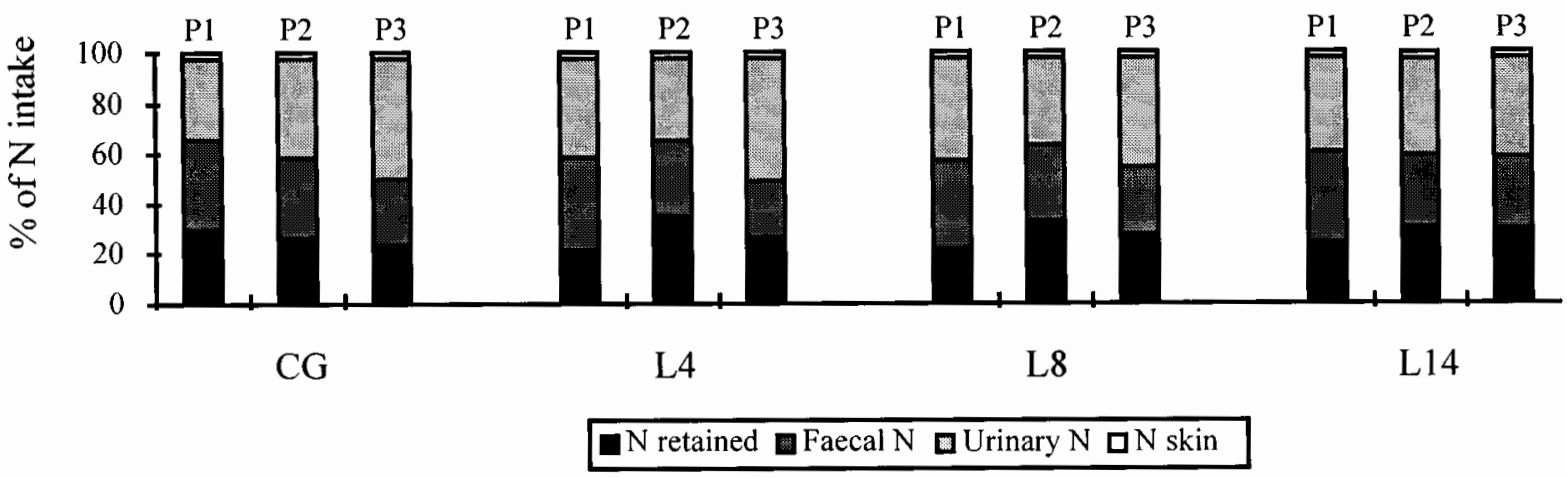

Fig. 2. Components of $\mathrm{N}$-balance as expressed in percent of $\mathrm{N}$-intake for three measurement periods: low growth (P1), rapid growth (P2), and 1 mo before slaughter (P3) for 3 treatment groups differing in length of the period of low growth (114 d for L4, $243 \mathrm{~d}$ for L8 and 419 $\mathrm{d}$ for L14) and for a control group (CG) at corresponding times.

account, to some extent, the differences in animal weight (Table 3).

The fractional rate of accretion $(\mathrm{Kg})$ tended to decline in the $\mathrm{CG}(P<0.1)$. During restriction $\mathrm{Kg}$ was at about $0.35 \%$ in the three restricted groups, and different from the $\mathrm{CG}$ $(P<0.001)$. In L4 and L8, it increased sharply during compensatory growth $(P<0.05)$ and decreased to $0.67 \%$ at $1 \mathrm{mo}$ before slaughter. In L14, it doubled to $0.74 \%$ in $\mathrm{P} 2$ $(P<0.01)$ and remained at this level towards the end of the experiment.

The fractional degradation rate $(\mathrm{Kd})$ of MP declined numerically in CG. Kd was low during RGP, with values of about $0.6 \%$, which were significantly different from CG ( $P<0.01$ for L4 and $P<0.05$ for L8 and L14). During compensatory growth, Kd tripled in L4 and doubled $(P<0.05)$ in L8 while it did not change in L14. At 1 mo before slaughter it declined in L4, and continued to rise in L8 and L14, although to a lesser extent in the latter.

The fractional synthesis rate of skeletal MP (Ks) tended to decline from P1 and P2 to 1 mo before slaughter in the CG $(P<0.06)$. It was, at about $1 \%$, lower than $\mathrm{CG}$ in the restricted groups during $\mathrm{P} 1(P<0.001$ for L4 and L14, $P<0.01$ for L8) and increased during compensatory growth. The extent of the increase was inversely proportional to time of restriction. At 1 mo before slaughter, $\mathrm{Ks}$ tended to decrease in L4 $(P<0.08)$ as opposed to the other groups, in which it remained high.

The efficiency of MPA, as expressed by the ratio $\mathrm{Kg} / \mathrm{Ks}$ (\%), decreased in CG $(35,30$, and $29 \%)$. In L4, accretion efficiency remained almost constant during the whole experimental period. In L8, a numerical increase from 30 to $39 \%$ (NS) was followed by a decrease to $28 \%$ (NS). In contrast, in L14, a large increase from 38 to $62 \%$ during compensatory growth $(P<0.01)$ was followed by a decrease to $55 \%(\mathrm{NS})$ at the end of the experimental period.

\section{DISCUSSION}

\section{N Balance}

Animal liveweight gain responded, as expected, to the transition from the restriction to the fattening diet by increasing from about $0.5 \mathrm{~kg} \mathrm{~d}^{-1}$ to around $1.5 \mathrm{~kg} \mathrm{~d}^{-1}$. A similar pattern was observed for $\mathrm{N}$ balance. The mean increase in $\mathrm{N}$ balance in the restricted groups ( $\Delta$ Nret) from Periods 1 to 2 was 42 to $45 \mathrm{~g} \mathrm{~d}^{-1}$. This implies that to increase liveweight by $1 \mathrm{~kg}, 42$ to $45 \mathrm{~g}$ additional $\mathrm{N}$ had to be retained. This is quite a bit higher than the normally accepted value of 32 to $35 \mathrm{~g}$ $\mathrm{N}$ fixed per kg liveweight gain deposited. However, BBDM bulls, with their extensive muscle development, retain slightly more $\mathrm{N}$ per kilogram liveweight gain than do animals of other breeds with less developped muscle mass. Finally, $\mathrm{N}$ losses by evaporation and transpiration, although taken into account and expressed as a fraction of metabolic body weight, could possibly be higher in these animals which have a large body surface.

The higher $\mathrm{N}$ retention during compensatory growth as compared with the LGP may be ascribed simply to a quantitatively higher $\mathrm{N}$ input (and consequently a higher quantity of digested $\mathrm{N}$ ) but also to an effect on digestibility per se (i.e., higher quality $\mathrm{N}$ and a more adequate amino acid supply). Apparent digestibility rose from 64 to about $70 \%$ in all groups that were previously restricted, while in the $\mathrm{CG}$, the digestibility only rose from 65 to $67 \%$. This could be a reflection of the intrinsic difference in the digestibility of the two diets. The increase in digestible $\mathrm{N}(\Delta \mathrm{Ndig})$ between $\mathrm{P} 1$ and P2 may be expressed as a function of both the increase in $\mathrm{N}$ intake ( $\Delta$ Nintake) or energy intake ( $\Delta$ MEintake) over the same time interval. The ratio $\Delta \mathrm{Ndig} / \Delta \mathrm{N}$ intake was higher for CG (0.93) than for the other three restricted groups, which had values around 0.74 to 0.79 . For the ratio $\Delta \mathrm{Ndig} / \Delta \mathrm{ME}$ intake, a similar pattern was observed, indicating no interaction between $\mathrm{N}$ and energy with regard to $\mathrm{N}$ digestibility.

Similarly, the question could be raised as to whether the increase in $\mathrm{N}$ retention upon changing to the fattening ration could be caused by a better metabolic $\mathrm{N}$ utilisation as reflected by a decrease in urinary $\mathrm{N}$ excretion. In absolute values, urinary $\mathrm{N}$ excretion was lower during restriction in all three groups compared with the CG. However, during this period Nurine/Nintake was higher in all three groups than in the $\mathrm{CG}$, which may be associated with a lower $\mathrm{N}$ quality in the restricted diet. Urinary $\mathrm{N}$ increased from $\mathrm{P} 1$ to P2 by about 20 to $25 \mathrm{~g} \mathrm{~N} \mathrm{~d}^{-1}$ in CG, L4, and L8. In L14 this 

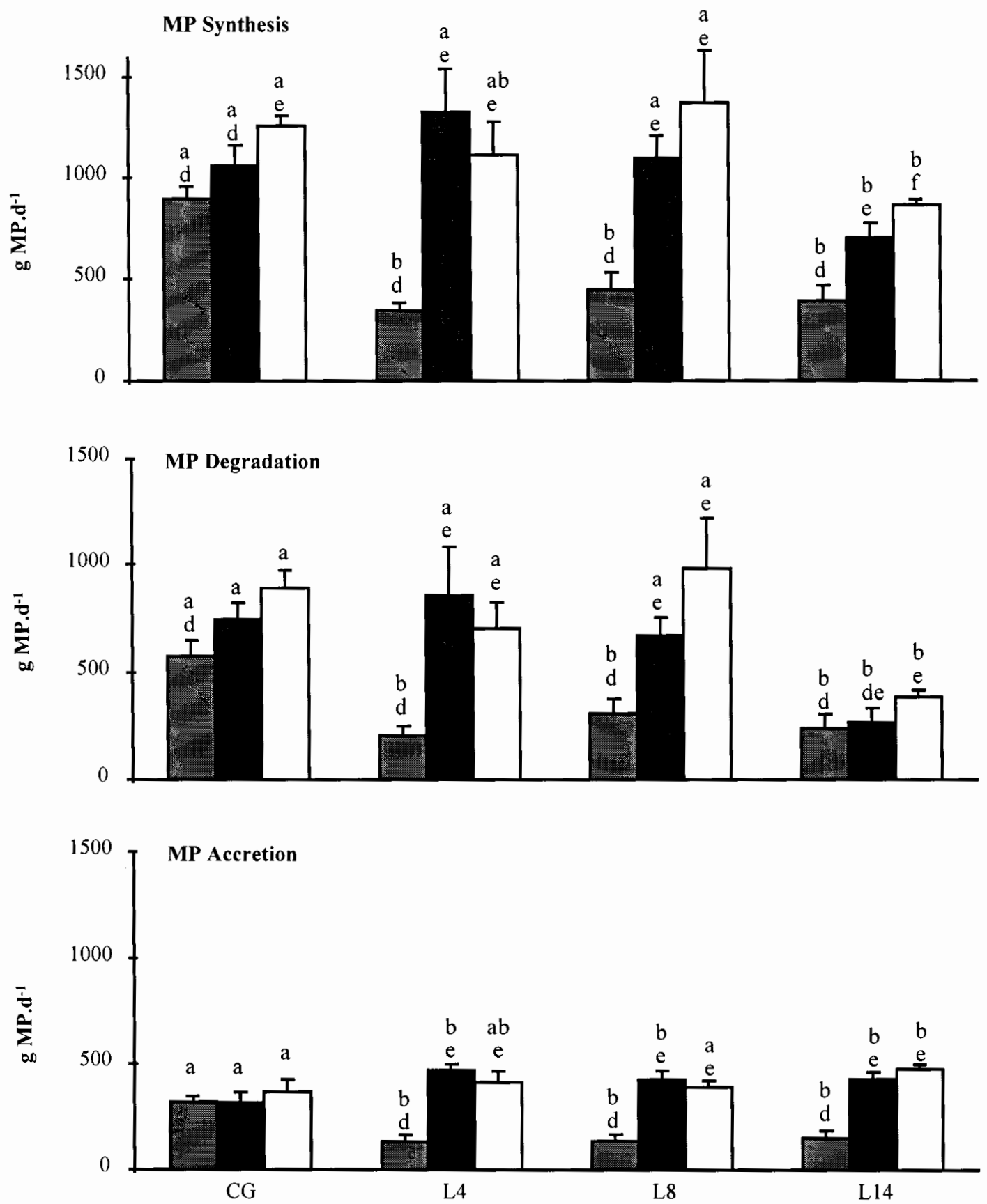

\section{Period $1 \square$ Period $2 \square$ Period 3}

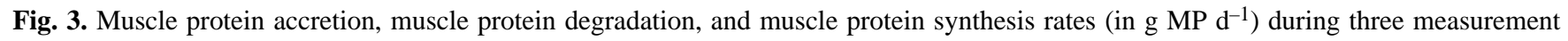
periods: low growth (Period 1), rapid growth (Period 2), and 1 mo before slaughter (Period 3) for three treatment groups differing in length of the period of low growth (114 d for L4, $243 \mathrm{~d}$ for L8 and $419 \mathrm{~d}$ for L14) and for a control group (CG) at corresponding times: means \pm standard deviation.

$a-c$ Effect of group. Means within a period, referring to similar items (e.g. MP synthesis, MP degradation or MP accretion) with different superscripts differ at $P<0.05$

$d-f$ Effect of period. Means within a group, referring to similar items (e.g. MP synthesis, MP degradation or MP accretion) and with different superscript differed at $P<0.05$. 
Table 4. Fractional rates (\%) of MP synthesis (Ks), MP degradation (Kd), and MP accretion (Kg) calculated with an estimate of MP pool based on slaughter weight, carcass and muscle longissimus dorsi composition during three measurement periods: low growth(Period 1), rapid growth (Period 2), and 1 mo before slaughter (Period 3 ) for 3 treatment groups differing in length of the period of low growth (114 d for L4, $243 \mathrm{~d}$ for L8 and $419 \mathrm{~d}$ for L14) and for a control group (CG) at corresponding times

\begin{tabular}{|c|c|c|c|c|c|c|c|}
\hline \multirow[b]{2}{*}{ Item } & & \multicolumn{4}{|c|}{ Group } & \multirow[b]{2}{*}{$P<F$} & \multirow[b]{2}{*}{ SEM } \\
\hline & & $\mathrm{CG}$ & L4 & L8 & L14 & & \\
\hline \multicolumn{8}{|l|}{ Period 1} \\
\hline MP Synthesis & $\mathrm{Ks}$ & $2.62 a$ & $0.93 b d$ & $1.17 b$ & $0.88 b$ & $* * *$ & 0.180 \\
\hline MP Degradation & $\mathrm{Kd}$ & $1.69 a$ & $0.57 b$ & $0.82 b$ & $0.55 b$ & $* * *$ & 0.159 \\
\hline MP Accretion & $\mathrm{Kg}$ & $0.92 a$ & $0.36 b d$ & $0.35 b d$ & $0.34 b d$ & $* * *$ & 0.050 \\
\hline \multicolumn{8}{|l|}{ Period 2} \\
\hline MP Synthesis & $\mathrm{Ks}$ & $2.35 a$ & $3.05 a e$ & $2.35 a$ & $1.20 b$ & * & 0.333 \\
\hline MP Degradation & $\mathrm{Kd}$ & $1.64 a$ & $1.98 a$ & $1.43 a$ & $0.46 b$ & $*$ & 0.294 \\
\hline MP Accretion & $\mathrm{Kg}$ & $0.71 a$ & $1.07 \mathrm{ce}$ & $0.92 a c$ & $0.74 a b e$ & + & 0.089 \\
\hline \multicolumn{8}{|l|}{ Period 3} \\
\hline MP Accretion & $\mathrm{Kg}$ & 0.59 & $0.66 e$ & 0.68 & 0.74 & + & 0.067 \\
\hline MP Degradation & $\mathrm{Kd}$ & $1.41 a$ & $1.13 a$ & $1.73 a$ & $0.6 \mathrm{~b}$ & $*$ & 0.247 \\
\hline MP Synthesis & $\mathrm{Ks}$ & 2.0 & $1.8 \mathrm{e}$ & $2.41 \mathrm{de}$ & $1.34 e$ & NS & 0.288 \\
\hline \multicolumn{8}{|l|}{$P<F$} \\
\hline MP Accretion & & NS & $*$ & NS & NS & & \\
\hline MP Degradation & & NS & $*$ & NS & NS & & \\
\hline MP Synthesis & & NS & $* * *$ & + & $* * *$ & & \\
\hline
\end{tabular}

$\overline{a-c}$ Effect of group. Means with different letters within a row differed at $P<0.05$

$d-f$ Effect of period. Means referring to similar items and with different letters within a column differed at $P<0.05$.

+ , ${ }^{*}$,***** $P<0.1, P<0.05, P<0.01$, and $P<0.001$, respectively; NS, not significant.

increase was twice as high, with a value of $51 \mathrm{~g} \mathrm{~N} \mathrm{~d}^{-1}$. This higher urinary $\mathrm{N}$ excretion during accelerated growth may result from a higher $\mathrm{N}$ intake as animal weight was higher during P2. However, when expressed in terms of $\Delta \mathrm{N}$ intake, $\Delta \mathrm{Nur} / \Delta$ Nintake was 0.93 in the $C G$, but much lower in the compensatory growth groups $(0.27$ for L4 and L8 and 0.41 for L14). So, apparently, compensatory growth was also achieved in part by a more efficient utilisation of the additional increment in $\mathrm{N}$ supply, the highest response in this regard being observed for the shorter restriction periods.

In the transition from restricted to accelerated growth periods, not only did the quantities of feed ingested increase, but diet composition also changed. The diet in the compensatory growth period was richer both in protein and in energy, having 15.68 vs. $11.37 \%$ crude protein, and 10.62 vs. $7.31 \mathrm{MJ} \mathrm{ME} \mathrm{kg}{ }^{-1}$ dry matter, compared with the diet offered during restricted feeding. So, are the contributions of both $\mathrm{N}$ digestibility and metabolic utilisation to the improvements in $\mathrm{N}$ balance between the two periods due to the increase in $\mathrm{N}$ intake or to the increase in energy intake or to both, and could there possibly be an interaction between the two factors?

When expressed both on a per-animal per day basis or correspondingly on a $\mathrm{kg}^{-0.75} \mathrm{LW}$ basis, $\Delta$ Nret/ $\Delta$ Nintake declined from L4 to L8, and from L8 to L14, with values of $0.51,0.40$, and 0.36 animal $^{-1} \mathrm{~d}^{-1}$, respectively, and values of $0.57,0.43$, and $0.39 \mathrm{~d}^{-1} \mathrm{~kg}^{-0.75} \mathrm{LW}$ respectively, indicating that 51,40 , and $36 \%$ of the supplemental $\mathrm{N}$ intake, respectively, was fixed in the animal. A similar evolution was observed when $\Delta$ Nret was expressed as a function of $\Delta \mathrm{ME}$ intake, although results were of course numerically differ-

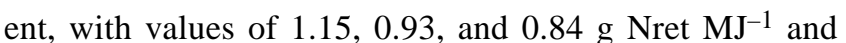

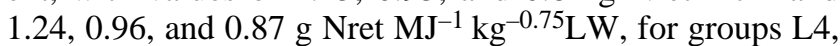
$\mathrm{L} 8$, and L14, respectively.

Although not statistically tested, there appeared to be no specific effects or interactions between $\mathrm{N}$ and energy intake on $\mathrm{N}$ retention when comparing $\mathrm{L} 4, \mathrm{~L} 8$, and $\mathrm{L} 14$, if we refer to the similarity between the ratio $\Delta \mathrm{Nret} / \Delta$ Nintake and $\Delta \mathrm{Nret} / \Delta \mathrm{ME}$, the former being 100 for L4, 78.4 for L8 and 70.6 for L14, while the latter was $100,80.0$, and $73 \%$, respectively, the value for L4 being set arbitrarily at $100 \%$.

So, apparently, and as observed for $\mathrm{N}$ metabolisability (urinary $\mathrm{N}$ excretion), the efficiency of increase in $\mathrm{N}$ retention was the highest after the shortest restriction period (L4). This could be ascribed to the fact that animal metabolism was less impaired or less adapted during shorter than during longer feed restriction, the metabolic machinery being still more complete. However, animal age could also intervene, as the animals during the shorter restriction periods were younger and thus metabolically more efficient.

From the preceeding results, it appears that during the compensatory growth period 40 to $50 \%$ of the increment of $\mathrm{N}$ intake is fixed in the animals. What now is the fate of other fractions, such as $\mathrm{N}$ originating from degradation of MP?

When $\Delta$ Nexcretion derived from the difference in MP degradation estimated from urinary $3 \mathrm{MH}$ excretion $(\triangle \mathrm{MPD})$ between the periods of slow and accelerated growth and expressed as $\mathrm{g} \mathrm{N}$ per day $\left(\triangle \mathrm{MPD} \times 6.25^{-1}\right)$ was related to $\Delta$ Nintake, this ratio was $1.15,0.58$ and 0.04 for L4, L8 and L14, respectively, when calculated on a per animal basis, and 1.3, 0.61, and -0.04 respectively when 
expressed per $\mathrm{kg}^{0.75} \mathrm{LW}$. Such changes indicate that in $\mathrm{L} 4$ for each additional $\mathrm{g} \mathrm{N}$ ingested, an additionnal $1.15 \mathrm{~g} \mathrm{~N}$ derived from MPD which was partly excreted and partly reutilised, while in $\mathrm{L} 8$ this increase in $\mathrm{N}$ excretion derived from MPD was only $0.58 \mathrm{~g}$ and, in L14, there was effectively no additional excretion of $\mathrm{N}$ from MPD. Expressed per $\triangle \mathrm{ME}$ intake the evolution between groups was similar. So, apparently, intracellular recycling of amino acids into muscle protein was much more efficient in L4 and L8. This intracellular recycling of amino acids during compensatory growth has been demonstrated by hindquarter arteriovenous difference measurements with similar animals (Hornick et al. 1997).

\section{Muscle Protein Turnover}

The term "protein turnover" is rather ambiguous. Normally it should be understood as the whole process of continuous degradation and synthesis of body proteins. Often the term is equated to protein degradation. Millward (1981) argues that any examination of protein turnover should start with the process of protein degradation, since it is this process which creates the need for protein resynthesis and results in the phenomenon of protein turnover. The authors emphasize further that the study of protein degradation is complicated by the fact that in comparison to protein synthesis, its mechanisms are less well understood and its rate is more difficult to measure, especially in vivo. This is particularly true for MP degradation.

In the following paragraphs MP turnover is understood as the whole process of MP synthesis and MP degradation.

The use of $3 \mathrm{MH}$ as a noninvasive index of in vivo myofibrillar MPD was validated in cattle by Harris and Milne (1981) and Nishizawa et al. (1979). There has been a controversy about the importance of the contribution of skeletal MP to the pool of urinary $3 \mathrm{MH}$, compared with the non-skeletal muscle contribution, especially taking the relative turnover rates of both pools into consideration (Millward et al. 1980; Harris 1981). Nevertheless, there are positive arguments for this approach, including a noninvasive method that is utilizable in vivo with large and expensive animals with a low degree of animal stress, as well as the possibility to estimate skeletal MP turnover, rather than whole body protein turnover. This method also complies with recent recommendations suggested at the 7th Protein Congress of the European Association for Animal Production (EAAP) in Santarem (1995) advocating noninvasive, less disturbing methodologies for research in animal physiology and nutrition.

A similar approach to ours was previously used by Lanka and Broderick (1980), Van Eenaeme et al. (1983, 1992), McCarthy et al. (1983), Gopinath and Kitts (1984), Jones et al. (1990), and Wheeler and Koohmaraie (1992).

As seen in Fig. 3, during restriction all components related to MP turnover were reduced. During compensatory growth they increased sharply. The fractional rates of MPS and MPD in the present experiment were somewhat lower than those reported by Jones et al. (1990), McCarthy et al. (1983), and Gopinath and Kitts (1984), the latter reporting Kd values only, but agreed more with recent observations from Wheeler and Koohmaraie (1992). This could be due to differences between breeds and conformation (double muscling vs. normal), but possibly also to the estimation of muscle protein pool size. In the current study, muscle protein was determined from analysis of carcass composition, whereas the other authors estimated muscle mass as a percentage of body weight. Jones et al. (1990) postulated muscle mass to be 35\% of body weight, Gopinath and Kitts (1984) used 33\% while McCarthy et al. (1983) derived skeletal muscle protein as being $55 \%$ of empty body protein, obtained as $30.17 \%$ of empty body weight, measured by the deuterium oxide method. In BBDM skeletal muscle mass is much higher, as measured muscle was $74.7 \%$ of the carcass and with a killing out percentage of 64.3 , muscle mass amounted to $48.0 \%$ of body weight, which is a typical value for BBDM. Such values were a lot higher than those used by the former authors. In this context, it is not surprising that the approach of Wheeler and Koohmaraie (1992), who estimated MP pool size by a regression with urinary creatinine excretion, was more in accordance with our approach, in which carcass composition and muscle protein content were measured.

Finally, in our experiment $\mathrm{Kg}$ was distinctly higher than in the above cited papers. This could be ascribed to a breed effect, as the Belgian Blue is known to be a slow "turning over" breed that deposits large amounts of muscle protein with highly-tuned rates of synthesis and degradation. So, during compensatory growth, MPS and MPD rates were both increased, the former, however, to a larger extent. Our observations regarding skeletal muscle protein synthesis in energy restricted cattle are in line with Kelly et al. (1993) who reported that with increasing levels of ME intake the rates of hindlimb protein synthesis relative to whole body protein synthesis rose, indicating that skeletal muscle is more sensitive to the nutrient supply than are visceral tissues. The effect of realimentation following restriction was different in the three groups. In L4 and L8 both synthesis and degradation rates increased, while in L14, which had the longest restriction period, the increase in MPA was slower, more persistent and could be ascribed almost entirely to an increase in MPS. At the end of the compensatory growth period, the bulls in L14 were about 8 mo older, with therefore a higher degree of sexual maturity and consequently higher testosterone levels, which may have been implicated in a higher and more prolonged anabolic response upon refeeding. At the end of the restriction period, the bulls of L14 had also lost, to some extent, their double muscling appearance. In this case growth was more in stature than in muscle mass development.

Although in absolute terms MPS and MPD rates were lower during the restricted feeding period, the efficiency of MPA, as expressed by the ratio MPA/MPS, was surprisingly rather similar in both control and restricted feeding groups, with values of $35.5,38.8,30.4$, and $38.2 \%$, for CG, L4, L8 and L14, respectively. So, a high growth rate at $1.3 \mathrm{~kg} \mathrm{~d}^{-1}$ in CG and low growth rates at $0.5 \mathrm{~kg} \mathrm{~d}^{-1}$ in L4, L8, and L14 were apparently equivalent with regard to MPA efficiency.

Continuing with a similar type of analysis as was done for the $\mathrm{N}$ balance parameters, the evolution of the components of MP turnover during the transition from restricted to 
fattening diet could be expressed as a function of the $\Delta \mathrm{N}$ intake or $\triangle \mathrm{ME}$ intake. $\triangle \mathrm{MPS}$ (in $\mathrm{g} \mathrm{N} \mathrm{d}^{-1}$ ) declined from $\mathrm{L} 4$ to $\mathrm{L} 8$, and from $\mathrm{L} 8$ to $\mathrm{L} 14$ when related to $\Delta \mathrm{N}$ intake (1.75, 0.94 , and 0.40 , respectively) and similarly when related to $\triangle \mathrm{ME}$. In contrast, $\triangle \mathrm{MPD}$ was substantially higher in L8 (0.85) than in the two other groups $(0.53$ and 0.15 , respectively). The difference could be related to higher plasmatic triiodothyronine concentrations observed during RGP in this group (Hornick et al. 1998), especially at the end of the RGP $\left(2 \pm 0.23\right.$ vs. $0.8 \pm 0.45$ and $1.1 \pm 0.48 \mathrm{nmol} \mathrm{mL}^{-1}$ in L8, L4 and L14, respectively).

It is usually accepted that during a period of restricted growth, when $\mathrm{N}$ and energy supplies are limited, the animals will presumably spare $\mathrm{N}$ by maximizing amino acid recycling for MPS while degradation does not change. However, in this experiment, and on the assumption that $3 \mathrm{MH}$ reflects mainly skeletal muscle protein degradation, the present results actually indicate a reduction of MPD during feed restriction. Thus, a slow growth rate was obtained at a reduced rate of MP turnover, both synthesis and degradation. In contrast, during compensatory growth both components of MP turnover increased. The foregoing observations lead to the already many times formulated question: what is the purpose of MP turnover? As already stated above (Millward et al. 1981) MPD plays a capital role as it is the drive for protein re-synthesis. So MPD directs synthesis and therefore the resulting anabolic achievement. Lobley (1993) proposed several roles for MP turnover: 1) heat production derived from MPS and probably also from MPD, 2) remodeling of tissue associated with growth, pregnancy and lactation, 3) rapid direction of continuously mobilized amino acids into specialized vital tasks at the expense of less vital tissue, especially skeletal muscle, during a period of feed restriction, 4) use of protein stores from skeletal muscle as additional sources of energy in submaintenance conditions and provision of suitable carbon sources for the biosynthesis of glucose, neurotransmitters and thus aid for homeostasis. The author concludes that optimal tuning of synthesis and degradation rates is capital as changes of only $0.1 \%$ in these rates can effect anabolic alterations of $20-100 \%$. In the current study the changes in MP synthesis and degradation rates between restricted and compensatory growth, as measured by our approach, are quite large and should therefore result in appreciable anabolic changes.

Finally, in vivo MP turnover could be related to meat quality. Meat tenderness is determined by collagen content and the degree of cross-linking (basic toughness), as well as proteinase activities during postmortem meat ageing and maturation. Thus, there might be a relationship between in vivo MPD and postmortem tenderization. In an experiment with Belgian Blue dual purpose type young bulls undergoing restricted feeding and subsequent compensatory growth, Van Eenaeme et al. (1994) found no relationship between MPD before slaughter and postmortem activities of cathepsins B and L, nor of the $\mu$ - and m-calpains, although for the latter, differences were observed between control and compensatory growth groups, with $\mu$-calpain activities being reduced and m-calpain activities increased. Warner-Bratzler shear force was not affected by treatment, either. In the pre- sent experiment, shear force tended to be lower in L4 $(P<0.10)$ and especially L8 $(P<0.05)$ but not in L14 (NS), when compared to $\mathrm{CG}$, with values of 40.3, 33.6, 29.6, and 38.0 Newtons, for CG, L4, L8, and L14, respectively. MPD 1 mo before slaughter was the highest (NS) for L8 but lower than CG for L4 and L14. The higher shear force in L14 could be related to the lower MPD, but presumably also to increased basic toughness as the bulls were older. From these data no clear relation can be seen: compensatory growth "young" meat seemed to be related to a lower shear force and a higher MPD in L8 but not in L4 whereas on the other side of the scale (L14) a higher shear force is associated with a lower MPD.

In an experiment with pigs on a protein deficient diet, Van den Hemel-Grooten et al. (1995) measured de novo $3 \mathrm{MH}$ production rate and proteinase activities to quantify skeletal muscle breakdown. Fractional breakdown rate was higher for the protein-free group but no differences were observed in activities of cathepsins B and L, $\mu-$ and $\mathrm{m}$ calpains, and corresponding inhibitors and MCP in longissimus and masseter muscles, except for a reduction of the MCP-activity in masseter on the protein-deficient diet. The authors propose two explanations for the lack of relationship between FBR and proteinase activities. Firstly, other proteinases responsible for the rate-limiting step in myofibrillar breakdown may be involved, and secondly, proteinase activities, measured in vivo, reflect potential capacity and not necessarily physiological activity of these enzymes. So a relationship between in vivo MP turnover and postmortem proteinase activities and the resulting meat tenderization is apparently not straightforward. In this context, it might be interesting to try measuring proteinase activities on in vivo muscle samples obtained by needle biopsy techniques.

During compensatory growth occurring after periods of reduced growth of different lengths, $\mathrm{N}$ retention increased as a result of both improved $\mathrm{N}$ digestibility and efficiency of $\mathrm{N}$ metabolisability. Accelerated growth in the compensatory growth phase was obtained by modulation of MP turnover in different ways. After a short period of restriction (L4), compensatory growth operated by enhancement of both MPS and MPD rates, the former being stimulated to a larger extent. The response was high and rapid but did not last until slaughter. After a longer period of restriction (L8), the response was similar but was observed to a lesser extent and lasted longer. Finally, after a very long period of restriction, compensatory growth was achieved mainly by stimulation of MPS. The amplitude of the response was lower but lasted longer. No clear relationship was observed between MP turnover and meat tendernesss.

\section{ACKNOWLEDGEMENTS}

DG6, the General Direction for Research and Development from the Belgian Ministry of Small Enterprises, Traders and Agriculture (formerly IRSIA, Institut pour l'Encouragement de la Recherche dans l'Industrie et l'Agriculture, Brussels, Belgium) is gratefully acknowledged for financial help.

Gopinath, R. and Kitts, W. D. 1984. Growth, $N \tau$-methylhistidine excretion and muscle protein degradation in growing beef steers. J. 
Anim. Sci. 59: 1262-1269.

Harris, C. I. 1981. Reappraisal of the quantitative importance of non-skeletal-muscle source of $\mathrm{N} \tau$-methylhistidine in urine. Biochem. J. 194: 1011-1014.

Harris, C. I. and Milne, G. 1981. The urinary excretion of $N \tau$ methylhistidine by cattle: validation as an index of muscle protein breakdown. Br. J. Nutr. 45: 411-422.

Haverberg, L. N., Deckelbaum, C., Bilmazes, C., Munro, H. N. and Young, V. R. 1975. Myofibrillar protein turnover and $N \tau$ methylhistidine output. Biochem. J. 152: 503-510.

Hornick, J. L., Van Eenaeme C., Diez M., Minet V. and Istasse L. 1997. Comparison of hindquarter metabolite uptake in Belgian Blue double-muscled bulls at maintenance or during fattening. J. Anim. Sci. 75: 3331-3341.

Hornick, J. L., Van Eenaeme C., Diez M., Minet V. and Istasse L. 1998. Different periods of feed restriction before compensatory growth in Belgian Blue bulls: II. Plasma metabolites and hormones. J. Anim. Sci. 76: 260-271.

Istasse, L., Van Eenaeme, C., Evrard, P., Gabriel, A., Baldwin, P., Maghuin-Rogister, G. and Bienfait, J. M. 1990. Animal performance, plasma hormones and metabolites in Holstein and Belgian Blue growing fattening bulls. J. Anim. Sci. 68: 2666-2673.

Jones, S. J., Starkey, D. L., Calkins, C. R. and Crouse, J. D. 1990. Myofibrillar protein turnover in feed-restricted and realimented beef cattle. J. Anim. Sci. 68: 2707-2715.

Kelly, J. M., Park, H., Summers, M. and Milligan L. P. 1993. Interactions between protein and energy metabolism. Pages 341-362 in J. M. Forbes and J. France, eds. Quantitative aspects of ruminant digestion and metabolism. CAB, Wallingford, UK.

Lanka, K. E. and Broderick, G. A. 1980. Estimation of protein turnover from $\mathrm{N}$ retention and urinary 3-methylhistidine excretion in steers. J. Anim. Sci. 51: 377.

Lobley, G. E. 1993. Protein metabolism and turnover. Pages 313-339 in J. M. Forbes and J. France, eds. Quantitative aspects of ruminant digestion and metabolism. CAB, Wallingford, UK.

McCarthy, F. D., Bergen, W. G. and Hawkins, D. R. 1983. Muscle protein turnover in cattle of differing genetic backgrounds as measured by urinary $\mathrm{N} \tau$-methylhistidine excretion. 1983. J. Nutr. 113: 2455-2463.

McKenzie, S. L. andTenaschuk, D. 1979a. Quantitative formation of $\mathrm{N}(\mathrm{O}, \mathrm{S})$-heptafluorobutyryl isobutyl amino acids for gas chromatographic analysis. Esterification. J. Chromatogr. 171: 195-208.
McKenzie, S. L. and Tenaschuk, D. 1979b. Quantitative formation of $\mathrm{N}(\mathrm{O}, \mathrm{S})$-heptafluorobutyryl isobutyl amino acids for gas chromatographic analysis. Acylation. J. Chromatogr. 173: 53-63. Millward, D. J., Bates, P. C. and Rosochaki, S. 1981. The extent and nature of protein degradation in the tissues during development. Reprod. Nutr. Develop. 21(2): 265-277.

Millward, D. J., Bates, P. C., Grimble, G. K., Brown, J. G., Nathan, M. and Rennie, M. J.. 1980. Quantitative importance of non-skeletal-muscle sources of $\mathrm{N} \tau$-methylhistidine in urine. Biochem. J. 190: 225-228.

Millward, D. J., Garlick, P. J., Stewart, A. J. C., Nnanyelugo, D. O. and Waterlow, J. C. 1975. Skeletal muscle growth and protein turnover. Biochem. J. 150: 235-243.

Nishizawa, N., Toyoda, Y., Noguchi, T. and Hareyama, S. 1979. $\mathrm{N} \tau$-Methylhistidine content of organs and tissues of cattle and an attempt to estimate fractional catabolic and synthetic rates of myofibrillar proteins of skeletal muscle during growth by measuring urinary output of $\mathrm{N} \tau$-methylhistidine. Br. J. Nutr. 42: 2 47-252. Van den Hemel-Grooten, H. N. A., Koohmaraie, M., Yen, J. T., Arbona, J. R., Rathmacher, J. A., Nissen, S. L., Fiorotto, M. L., Garssen, G. J. and Verstegen, M. W. A. 1995. Comparison between 3-methylhistidine production and proteinase activity as measures of skeletal muscle breakdown in protein-deficient growing barrows. J. Anim. Sci. 73: 2272-2281.

Van Eenaeme, C., Baldwin, P., Lambot, O. and Bienfait, J.M. 1983. Estimation of in vivo muscle protein turnover in young bulls treated with anabolic agents Pages 81-84 in R. Pion, M. Arnal, and D. Bonin, eds. Protein metabolism and nutrition. Publication no. 16.II. INRA, Paris, France.

Van Eenaeme, C., Clinquart, A., Baldwin, P., Hornick, J. L. and Istasse, L. 1992. Compensatory growth, muscle protein turnover and hormonal status in Belgian Blue bulls. Med. Fac. Landbouww. Univ. Gent. 57: 1963-1971.

Van Eenaeme, C., Clinquart, A., Uytterhaegen, L., Hornick, J. L., Demeyer, D. and Istasse, L. 1994. Postmortem protease activity in relation to muscle protein turnover in Belgian blue bulls with different growth rates. Sci. Alim. 14: 475-483.

Wheeler, T. L. and Koohmaraie, M. 1992. Effects of the $\beta$ adrenergic agonist L644,969 on muscle protein turnover, endogenous proteinase activities and meat tenderness in steers. J. Anim. Sci. 70: $3035-3043$. 